\title{
THE ROLE OF ORGANIZATIONAL COMMITMENT AS MEDIATION OF THE INFLUENCE OF ORGANIZATIONAL CULTURE AND LEADERSHIP ON EMPLOYEES' PERFORMANCE IN PROVINCIAL FOOD SECURITY AGENCY OF SOUTHEAST SULAWESI, INDONESIA
}

\author{
Sutra Dewi, Student \\ University of Halu Oleo Kendari, Indonesia \\ Dedy Takdir Syaifuddin, Bahana Adam, Lecturers \\ Faculty of Economics and Business, University of Halu Oleo Kendari, Indonesia \\ *E-mail: sutradewi811@gmail.com
}

\begin{abstract}
The objective of this research is to test and explain the influence of organizational culture on organizational commitment, the influence of leadership on organizational commitment, the influence of organizational culture on employees' performance, the influence of leadership on employees' performance, the influence of organizational commitment on employees' performance, the role of organizational commitment as mediation of the influence of organizational culture on employees' performance and the role of organizational commitment as mediation of the influence of leadership on employees' performance. This explanatory research employs a survey method, aiming at seeking the causal relationship between variables through hypothesis test. This research finds that: organizational culture positively, significantly influences the organizational commitment of the Provincial the Provincial Food Security Agency of Southeast Sulawesi; leadership positively, significantly influences the organizational commitment of the Provincial Food Security Agency of Southeast Sulawesi; organizational culture positively, significantly influences the employees' performance of the Provincial Food Security Agency of Southeast Sulawesi; and leadership positively, significantly contributes to organizational commitment, but does not significantly influence employees' performance.
\end{abstract}

\section{KEY WORDS}

Perceived organizational support, organizational culture, organizational commitment.

Human Resources Management is the planning, organization, direction and control related to an organization's formal design system to determine the effectiveness and efficiency of personnel's talent to realize organization's performance and objectives (Mathis and Jackson, 2011:14). A good organizational culture will influence employees' behavior, which will then lead to performance improvement. A number of studies shows that a good culture wills guide the behaviors of and give significance to organization's activities, thus the performance resulted will also be optimal. A leader's attitude and character in influencing others in an organization significantly determine how organization's objectives are achieved. Employees' loyalty may be observed from their willingness to continuously attempt to be part of the organization and their strong desire to stay in the organization.

Although theoretically, and many previous researches explain that, organizational culture and leadership result in employees' performance, but some studies and researches present different findings. Such different research results have been a gap of research, thus organizational commitment is added, which serves as a mediation variable. Organizational commitment as a mediation variable must show its influence on employees' performance. The researches that show that organizational commitment is able to mediate the influence of organizational culture on employees' performance are those conducted by Suryaningsih et al. (2018), Nikpour. A (2017) and Intan Cahya, K. et al. (2018), which find that organizational commitment serves as mediation of the influence of organizational culture on employees' 
performance. There is a contradiction between the findings of research conducted by Sujarwo et al. (2018), Isbandi, T.B et al. (2018) and Winardi (2016), that organizational commitment does not serves as mediation of the influence of organizational culture on employees' performance.

To maximize existing potential of the Provincial Food Security Agency of Southeast Sulawesi, Indonesia, it needs officers' good habit, officers' behavior and interaction between officers. A consistently good valuation system in an organization will support its good working procedure to implement an integrated food security building process in maximizing services given by officers of the Provincial Food Security Agency of Southeast Agency. Based on the description of background above, the researcher is interested to study further the influence of organizational culture and leadership, both directly and through organizational commitment as mediation in attempt to improve the performance of employees of the Provincial Food Security Agency of Southeast Sulawesi. This research may contribute to the development of theories for academics, particularly with regard to organizational culture, leadership, and organizational commitment as well as to give suggestion to the management of the Provincial Food Security Agency of Southeast Sulawesi, particularly in personnel management in formulating strategies, policies and programs for improvement of its organizational culture, leadership, organizational commitment and employees' performance.

\section{LITERATURE REVIEW}

Malthis and Jackson (2011:14) state that Human Resources Management is correlated with an organization's formal design system to determine the effectiveness and efficiency as viewed from an individual's talent to realize the organization's objectives. Robbins and Judge (2015:16) define Human Resources Management as part of management study focusing on how to recruit, employ, train, motivate and maintain employee.

According to Robbins and Coulter (2012), the definition of organizational culture implies three things. First, culture is a perception, instead of something which may be touched or seen physically, but is accepted and understood by employees through what they experience in organization. Second, culture is descriptive and related to how members accept and define such culture, regardless of whether they like it or not. Third, organizational culture is shared (acceptance aspect), that although individuals in organization have different backgrounds and works in far different stages, they tend to define and express organizational culture in the same way. Robbins and Judge (2015:384) state that leadership is the capability to influence a group to achieve their goals and objectives. Therefore, leadership leads to commitment of all subordinates and instills big trust in leader. According to Yukl (2013:4), leadership is individual's capability to influence, motivate, and make others contribute to organization's effectiveness and success.

Luthans (2011:147) finds that organizational commitment is often defined as: (1) strong willingness to remain becoming member of certain organization, (2) willingness to make high level effort on behalf of organization, and (3) certain belief in and acceptance of organization's values and objectives. Organizational commitment is employees' loyalty to organization, as reflected in their high involvement in achieving organization's objectives (Priansa, 2014). Employees' loyalty may be viewed from their willingness to continuously attempt to be part of organization, and their strong desire to remain in the organization. The concept of organizational commitment is correlated with individual's involvement level in the organization where they work and their interest to remain in the organization.

Sedarmayanti (2016:76) explains the definition of performance as deliverables achieved by an individual or a group of people in an organization pursuant to their respective authority and responsibility in attempt to achieve the concerned organization's objectives legally, instead of unlawfully, and pursuant to moral values and ethics.

Research's Hypothesis. Based on the research's frame of reference, the research's hypotheses are:

- H1: Organizational culture significantly influences organizational commitment;

- H2: Leadership significantly influences organizational commitment; 
- H3: Organizational culture significantly influences employees' performance;

- H4: Leadership significantly influences employees' performance;

- H5: Organizational commitment significantly influences employees' performance;

- H6: Organizational commitment serves as mediation of the influence of organizational culture on employees' performance;

- H7: Organizational commitment serves as mediation of the influence of leadership on employees' performance.

\section{METHODS OF RESEARCH}

This explanatory research takes a survey method, aiming at seeking the causal relationship between the influence of organizational culture and leadership on organizational commitment and employees' performance, both directly and indirectly (through mediation variable of organizational commitment), in the Provincial Food Security Agency of Southeast Sulawesi, Indonesia. The research's population is all employees of the Provincial Food Security Agency of Southeast Sulawesi, consisting of 70 Civil Servants, excluding the leader (Chairman of the Office). Therefore, there are 70 respondents, which mean that all of the population is taken as the research's respondents. The research's data are analyzed by using descriptive and statistical inference method of Partial Least Square (PLS).

\section{RESULTS AND DISCUSSION}

In the hypothesis test and path coefficient of direct influence between the variables of organizational culture, leadership and organizational commitment on employees' performance, four out of the five direct influences tested are positive and significant, which are organizational culture on organizational commitment, leadership on organizational commitment, organizational culture on employees' performance and organizational commitment on employees' performance. The complete data analysis results are presented below:

Table 1 - Path Analysis and Hypothesis Test of Direct Influence

\begin{tabular}{|c|c|c|c|c|c|}
\hline Hypothesis & Correlation between Variables & $\begin{array}{c}\text { Path } \\
\text { Coefficient }\end{array}$ & p-value & $\begin{array}{c}\alpha \\
\text { Alfa }\end{array}$ & \begin{tabular}{c} 
Result \\
\hline H1
\end{tabular} Organizational Culture $\rightarrow$ Organizational Commitment \\
H2 & Leadership $\rightarrow$ Organizational Commitment & 0.199 & 0.035 & 0.05 & Sig \\
\hline H3 & Organizational Culture $\rightarrow$ Employees' Performance & 0.360 & 0.000 & 0.05 & Sig \\
\hline H4 & Leadership $\rightarrow$ Employees' Performance & 0.049 & 0.574 & 0.05 & Sig \\
\hline H5 & $\begin{array}{c}\text { Organizational Commitment } \rightarrow \text { Employees' } \\
\text { Performance }\end{array}$ & 0.565 & 0.000 & 0.05 & Sig \\
\hline
\end{tabular}

Source: Output of PLS Model.

Based on the regression result shown, the hypothesis test may be explained below:

$\mathrm{H} 1$ : Organizational Culture Has a positive and significant impact on Organizational Commitment.

The test of organizational culture on organizational commitment results in estimate path coefficient value of 0.199 in positive direction. Positive path coefficient means that the influence between organizational culture and organizational commitment is irreversible. The significance result is proven with $p$-value of $0.035<0.05$, which is defined as significant influence. Based on the foregoing, we may conclude the result of hypothesis test $\left(\mathrm{H}_{1}\right)$ stating that organizational culture positively, significantly influences organizational commitment. This means an improvement of organizational culture leads to a good, irreversible, positive and significant improvement of organizational commitment, thus the proposed hypothesis is acceptable.

H2: Leadership positively, significantly influences organizational commitment. 
The test of leadership on organizational commitment results in estimate path coefficient value of 0.551 in positive direction. Positive path coefficient means that the influence between leadership and organizational commitment is irreversible and positive. The significance result is proven with $p$-value of $0.000<0.05$, which is defined as significant influence. The result of hypothesis test $\left(\mathrm{H}_{2}\right)$ stating that leadership positively, significantly influences organizational commitments acceptable. This means an improvement of leadership leads to a good, irreversible, positive and significant improvement of organizational commitment, thus the proposed hypothesis is acceptable.

H3: Organizational culture positively, significantly influences employees' performance.

The test of organizational culture on employees' performance results in estimate path coefficient value of 0.360 in positive direction. Positive path coefficient means that correlation between organizational culture and employees' performance is irreversible. The significance result is proven with $p$-value of $0.000<0.05$, which is defined as significant influence. The significance result is proven with p-value of $0.000<0.05$, which is defined as significant influence. The result of hypothesis test $\left(\mathrm{H}_{3}\right)$ proving that organizational culture positively, significantly influences employees' performance is acceptable. This means an improvement of organizational culture leads to a good, irreversible, positive and significant improvement of employees' performance, thus the proposed hypothesis is acceptable.

H4: Leadership positively, significantly influences employees' performance.

The test of leadership on employees' performance results in estimate path coefficient value of 0.049 in positive direction. Positive path coefficient means that the influence between leadership and employees' performance is irreversible. However, the test results in $p$-value of $0.574>0.05$, which is defined as insignificant influence. Based on the foregoing, we may conclude that the hypothesis test $\left(\mathrm{H}_{4}\right)$ stating that leadership positively, significantly influences employees' performance is not proven. This means an improvement of leadership leads to positive, insignificant improvement of employees' performance, thus the proposed hypothesis is not acceptable (rejected).

H5: Organizational commitment positively, significantly influences employees' performance.

The test of organizational commitment on employees' performance results in estimate path coefficient value of 0.565 in positive direction. Positive path coefficient means that correlation between organizational commitment and employees' performance is irreversible. The significance result is proven with $p$-value of $0.000<0.05$, which is defined as significant influence. Based on the foregoing, we may conclude that the hypothesis test $\left(\mathrm{H}_{5}\right)$ stating that organizational commitment positively, significantly influences employees' performance is proven. This means an improvement of leadership leads to positive, significant improvement of employees' performance, thus the proposed hypothesis is acceptable. The test on mediation influence aims at detecting the position of intervening variable in the model, and is conducted to determine the characteristics of correlation between variables, either as perfect mediation variable, partial mediation variable or non-mediation variable.

H6: Organizational commitment mediates the influence of organizational culture on employees' performance.

Based on the use of z-statistic formula developed by Sobel, the mediating effect of the organizational commitment variable in mediating the influence of organizational culture on employees' performance may be viewed from the result of Sobel test online based on the table as follows:

Table 2 - Mediating effect of organizational commitment variable in mediating the influence of organizational culture on employees' performance

\begin{tabular}{|c|c|c|c|c|}
\hline Mediating effect (indirect) & Path Coefficient & Statistical Test & $\begin{array}{c}\text { Std. } \\
\text { Error }\end{array}$ & $\rho-$ value \\
\hline Organizational culture $\rightarrow$ Organizational Commitment & 0.199 & 1.987 & 0.056 & 0.04 \\
\hline Organizational Commitment $\rightarrow$ Employees' Performance & 0.565 & 1.961 & 0.057 & 0.04 \\
\hline
\end{tabular}

Source: Sobel Test Result. 
The calculation result in the table shows that the $p$-value $=0.04<0.05$, which means that organizational commitment mediates the influence of organizational culture on employees' performance. Therefore, the hypothesis $\left(\mathrm{H}_{6}\right)$ is declared acceptable. The result of test on mediating role of organizational commitment the influence of organizational culture on employees' performance is explained below:

Table 3 - Result of Test with Mediation

\begin{tabular}{|c|c|c|}
\hline Correlation between Variables & Path Coefficient & $\rho$ Value \\
\hline Organizational Culture $\left(\mathrm{X}_{1}\right) \rightarrow$ Organizational Commitment $\left(\mathrm{Y}_{1}\right)$ & 0.477 & 0.001 \\
\hline Organizational Commitment $\left(\mathrm{Y}_{1}\right) \rightarrow$ Employees' Performance $\left(\mathrm{Y}_{2}\right)$ & 0.591 & 0.000 \\
\hline Organizational Culture $\left(\mathrm{X}_{1}\right) \rightarrow$ Employees' Performance $\left(\mathrm{Y}_{2}\right)$ & 0.373 & 0.000 \\
\hline
\end{tabular}

Source: Sobel Test Result Online.

Table 4 - Result of Test without Mediation

\begin{tabular}{|c|c|c|}
\hline Correlation between Variables & Path Coefficient & $\rho$ Value \\
\hline Organizational Culture $\left(\mathrm{X}_{1}\right) \rightarrow$ Employees' Performance $\left(\mathrm{Y}_{2}\right)$ & 0.694 & 0.000 \\
\hline
\end{tabular}

Source: Sobel Test Result Online.

Referring to the model test result in the Table above, we may observe that in the result of model test with mediation, the path coefficient value of the influence of organizational culture on organizational commitment and of organizational commitment on employees' performance is significant and organizational culture also significantly influences employees' performance. However, the coefficient value of the influence of organizational culture on employees' performance in the model test with mediation is lower (decreasing) of 0.373 than the coefficient value of the influence of organizational culture on employees' performance without involving organizational commitment variable of 0.694 . Therefore, based on classification of the type of mediation, the role of organizational commitment in the influence of organizational culture on employees' performance is classified in to partial mediation. This means that organizational culture may, directly or indirectly organizational commitment, influence employees' performance.

H7: Organizational commitment mediates the influence of leadership on employees' performance.

Based on the use z-statistic formula developed by Sobel, the mediating effect of organizational commitment variable in mediating the influence of leadership on employees' performance may is viewed from the result of Sobel test online based on table 5 as follows:

Table 5 - Mediating effect of organizational commitment variable in mediating the influence of leadership on employees' performance

\begin{tabular}{|c|c|c|c|c|}
\hline Mediating effect (indirect) & Path Coefficient & $\begin{array}{c}\text { Test } \\
\text { Statistic }\end{array}$ & $\begin{array}{c}\text { Std. } \\
\text { Error }\end{array}$ & $\begin{array}{c}\rho- \\
\text { value }\end{array}$ \\
\hline Leadership $\rightarrow$ Organizational Commitment & 0.551 & 3.781 & 0.082 & 0.000 \\
\hline Organizational Commitment $\rightarrow$ Employees' Performance & 0.565 & 3.749 & 0.083 & 0.000 \\
\hline
\end{tabular}

Source: Sobel Test Result Online.

The calculation result in the table shows that the $p$-value $=0.000<0.05$, which means that organizational commitment mediates the influence of leadership on employees' performance. Therefore, the seventh hypothesis is declared acceptable.

The result of test on mediating role of organizational commitment the influence of leadership on employees' performance is explained as follows:

Table 6 - Result of Test with Mediation

\begin{tabular}{|c|c|c|}
\hline Correlation between Variables & Path Coefficient & $\rho$ Value \\
\hline Leadership $\left(\mathrm{X}_{2}\right) \rightarrow$ Organizational Commitment $\left(\mathrm{Y}_{1}\right)$ & 0.652 & 0.000 \\
\hline Organizational Commitment $\left(\mathrm{Y}_{1}\right) \rightarrow$ Employees' Performance $\left(\mathrm{Y}_{2}\right)$ & 0.692 & 0.000 \\
\hline Leadership $\left(\mathrm{X}_{1}\right) \rightarrow$ Employees' Performance $\left(\mathrm{Y}_{2}\right)$ & 0.162 & 0.034 \\
\hline
\end{tabular}

Source: Sobel Test Result Online. 
Table 7 - Result of Test without Mediation

\begin{tabular}{|c|c|c|}
\hline Correlation between Variables & Path Coefficient & $\rho$ Value \\
\hline Leadership $\left(\mathrm{X}_{2}\right) \rightarrow$ Employees' Performance $\left(\mathrm{Y}_{2}\right)$ & 0.609 & 0.000 \\
\hline
\end{tabular}

Source: Sobel Test Result Online.

Referring to the model test result in the Table above, we may observe that in the result of model test with mediation, the path coefficient value of the influence of leadership on organizational commitment and of organizational commitment on employees' performance is significant and leadership also significantly influences employees' performance. However, the coefficient value of the influence of leadership on employees' performance with the model test with mediation is lower (decreasing) than the coefficient value of the influence of leadership on employees' performance without involving organizational commitment variable. Therefore, based on classification of the type of mediation, the role of organizational commitment in the influence of organizational culture on employees' performance is classified into partial mediation. This means that leadership may, directly or indirectly organizational commitment, influence employees' performance.

\section{DISCUSSION OF RESULTS}

Influence of Organizational Culture on Organizational Commitment of the Provincial Food Security Agency of Southeast Sulawesi. The research finds that organizational culture directly, positively, significantly influences the organizational commitment of the Provincial Food Security Agency of Southeast Sulawesi. This means that the better the organizational culture, the better it improves the organizational commitment in the Provincial Food Security Agency of Southeast Sulawesi. This is reasonable since organizational culture is included in the assessment, either when viewed from innovation and risk taking, job detail, result orientation, people orientation, aggressiveness and stability indicators. Some theories referred to in this research are proven, as those proposed by Hofstede (1980); Robbins and Judge (2015:35); and Robbins and Coulter (2012:82), that a good organizational culture will improve the sense of ownership and commitment of organization members and may eventually improve employees' performance, consistently with the opinions of Peters and Waterman, (1982) and Sopiah (2008) that organizational culture may greatly influence organizational performance and commitment. Furthermore, Robbins (2010) states that a strong culture generates high agreement among individuals, consistence level in behavior, togetherness, loyalty, and organizational commitment.

Influence of Leadership on Organizational Commitment of the Provincial Food Security Agency of Southeast Sulawesi. The research finds that organizational culture directly, positively, significantly influences the organizational commitment of the Provincial Food Security Agency of Southeast Sulawesi. This means that the better the leadership of Chairman of Office, the better it improves organizational commitment of the Provincial Food Security Agency of Southeast Sulawesi. This is reasonable since the leadership implementation of the Chairman of Office is included in the assessment, as reflected through leader's behavior of continuously giving instruction to the employees, giving moral support, participating when sub ordinates find difficulty and orienting to achieving high deliverables. This finding supports some previous researches conducted by Suryaningsih, et al. (2018) and Li Lin et al.(2018), that leadership positively, significantly influences organizational commitment. Saleh. M et al.(2018) asserts that better leadership results in higher employees' commitment. This research also asserts that the result of research conducted by Hermawati and Nasharuddin (2017) stating that leadership insignificantly influences employees' performance is not proven. This research supports the opinion of Nikpour A (2017) that organizational culture may improve employees' performance, thus the higher the values they feel when they are in the organization, the higher their desire to have better performance will be and does not support the researchers conducted by Harwiki (2016) and Suharno et 
al.(2017) showing that organizational culture negatively, insignificantly influences employees' performance.

Influence of Organizational Culture on Employees' Performance of the Provincial Food Security Agency of Southeast Sulawesi. The research finds that organizational culture directly, positively, significantly influences the employees' performance of the Provincial Food Security Agency of Southeast Sulawesi. This means that the better the organizational culture, the better it improves the employees' performance of the Provincial Food Security Agency of Southeast Sulawesi. The improvement of employees' performance is reflected through employees' valuation in the quality, quantity, time, service orientation, integrity, cooperation and employees' leadership aspects.

Influence of Leadership on Employees' Performance of the Provincial Food Security Agency of Southeast Sulawesi. The research finds that organizational culture directly, positively and significantly influences employees' performance of the Provincial Food Security Agency of Southeast Sulawesi. This means that the better the leadership of Chairman of Office, the better it influences the improvement of employees' performance of the Provincial Food Security Agency of Southeast Sulawesi in significantly. This is reasonable since although the leadership implementation of the Chairman of Office is included in the assessment, but there is a gap of leadership in the implementation. This research confirms the result that some previous researches conducted by Suryaningsih, et al. (2018), Fathia, M et al. (2018), Suharno, et al.(2017) and Srieati, L (2016) finding that leadership positively, significantly influences employees' performance is not proven and confirms the research conducted by Hermawati and Nasharuddin (2017) finding that leadership insignificantly influences employees' performance.

Influence of Organizational Commitment on Employees' Performance of the Provincial Food Security Agency of Southeast Sulawesi. The analysis finds that organizational commitment directly, positively and significantly influences the employees' performance of the Provincial Food Security Agency of Southeast Sulawesi. This means that the better the organizational commitment, the better the employees' performance of the Provincial Food Security Agency of Southeast Sulawesi will be. Organizational commitment is measured through affective commitment, continuous commitment and normative commitment indicators, while an improvement of employees' performance is reflected through employees' assessment in employees' quality, quantity, time, service orientation, integrity, cooperation and leadership aspects. This research result conforms to the previous research conducted by Zefeiti et al.(2017) and Suwibawa et al.(2018) that organizational commitment significantly influences employees' performance. The result of research conducted by Mahrani et al (2015) stating thatan improvement of organizational commitment also plays an important role in achieving employees' behavior in settlement of duties. Although theoretically, and various previous researches explain that, organizational culture and leadership result in employees' performance, but some studies and researches present different findings, such as that asserted by Sujarwo, et al.(2018),that organizational commitment does not influence employees' performance.

Influence of Organizational Culture on Employees' Performance with Mediation of Organizational Commitment. The research finds that organizational commitment mediates the influence of organizational culture on employees' performance of the Provincial Food Security Agency of Southeast Sulawesi. This means that organizational commitment may mediates the influence of organizational culture on employees' performance in the Provincial Food Security Agency of Southeast Sulawesi. This is reasonable since organizational commitment is the biggest variable to have direct effect on employees' performance, as proven by the fact that, in general, the implementation of organizational commitment is good, particularly with regard to affective commitment and normative commitment. The research result does not conform to the research conducted by Fathia, M, et al.(2018) that organizational commitment does not serve as mediation of the influence of leadership on employees' performance. However, Suryaningsih, et al. (2018) asserts that Organizational commitment mediates the influence of organizational culture on employees' performance. 
Furthermore, Winardi (2016) explains the role of organizational commitment as mediation of the influence of organizational culture on employees' performance.

Influence of Leadership on Employees' Performance with Mediation of Organizational Commitment. The research finds that organizational commitment mediates the influence of leadership on the employees' performance of the Provincial Food Security Agency of Southeast Sulawesi. This means that organizational commitment may mediate the influence of leadership on employees' performance of the Provincial Food Security Agency of Southeast Sulawesi. This condition is reasonable, since organizational commitment is the biggest variable to have direct effect on employees' performance, while leadership itself does not significantly influence employees' performance. Besides, field fact proves that leadership is not optimal in its implementation, particularly with regard to the weak participative leadership of the Chairman of Office, which directly influences the insignificant improvement of employees' performance.

\section{CONCLUSION}

This research results confirm to the research conducted by Li Lin et al. (2018) that organizational commitment plays a role in mediating correlation between leadership with employees' performance. However, a different finding is proposed by Fathia, M, et al.(2018) that organizational commitment does not serve as mediation of the influence of leadership on employees' performance.

\section{REFERENCES}

1. Al-Sada, M., Al-Esmael, B., and Faisal, M.N. (2017) 'Influence of organizational culture and leadership style on employee satisfaction, commitment and motivation in the educational sector in Qatar' EuroMedJournal of Business, Vol. 12 Issue: 2, pp.163-188, https://doi.org/10.1108/EMJB-02-2016-0003.

2. Al Zefeiti, S.M.B., and Mohamad, N.A. (2017) 'The Influence of Organizational Commitment on Omani Public Employees Work Performance' International Review of Management and Marketing ISSN: 2146-4405available at http: www.econjournals.com

3. Amstrong, M. (2009) Handbook of Management and Leadership: A Guide to Managing Result London. Kogan Page

4. Bennet Silalahi, (2004). Corporate Culture and Performance. Copyright. Yayasan Pendidikan Al Hambra. Jakarta

5. Dessler, G. (2015) Human Resource Management. Fourteenth Edition. London: Pearson Education.

6. Flippo, Edwin B. (2002). Personel Management (Manajemen Personalia), Edisi VII Jilid II, Terjemahan Alponso S, Erlangga, Jakarta.

7. Greenberg, J and Baron, Robert A. (2005). Behavior in Organization. New Jersey: Prentice Hall.

8. Goleman, D. (2004) Kepemimpinan Berdasarkan Kecerdasan Emosi. Bandung: PT. Gramedia Pustaka Utama.

9. Ghozali, Iman (2010). Model Persamaan Struktural Konsep and Aplikasi Dengan Program AMOS 19. Semarang:Badan Penerbit Universitas Diponegoro.

10. Greenberg, Jerald, (2010). Managing Behavior in Organization. USA: Pearson,

11. Harris, Michael, (2000). Human Resource Management. 2th Edition. The Dryden Press. USA.

12. Harwiki, W. (2016) 'The Impact of Servant Leadership on Organization Culture, Organization Commitment, Organizational Citizenship Behaviour (OCB) and Employee Performance in Women Cooperatives' Procedia - Social and Behaviour Sciences 219 (2016) 283-290.

13. Hofstede, G. (1980). Culture's Consequences: International Differences in Work- Related Values. Beverly Hills, CA and London: Sage Publication. 
14. Hofstede, G. (1994). Cultures and Organizations: Intercultural Cooperation and its Importance for Survival. London: Harper Collins Publisher.

15. Hermawati, A; Nasharuddin Mas, (2017). "Mediation effect of quality of worklife, job involvement, and organizational citizenship behavior in relationship between transglobal leadership to employee performance" International Jurnal of Law and Management, https://doi.org/10.1108/IJLMA-08-2016-0070.

16. Hersey, P. and Blanchard, K.H. (2002) Manajemen Perilaku Organisasi: Pendayagunaan Sumber Daya Manusia. Jakarta: Erlangga.

17. Indrawijaya, A. I. (2010) Perilaku Organisasi Sinar Baru. Bandung: Algasindo.

18. Isbandi, T.B; Rivai, A; and Suharto (2018). "The Effect of Organizational Culture and Career Development to Employee Performance through Organization Commitment on Directorate of Export of Agriculture and Forestry Products Ministry of Trade" International Journal of Arts Humanities and Social Sciences Volume 3 Issue 2 I February 2018. www.ijahss.com.

19. Kristianto, P.B. (2018). "The Influence of Leadership Style and Organizational Climate on Employee Performance through Organizational Commitment on Perum Pegadaian Branch East Bekasi" International Journal of Business and Applied Social Science (IJBASS), 4(6) June 2018 http://ijbassnet.com/ E-ISSN: 2469-6501.

20. Li Lin; Shiqian, W (2018). "The Mediating Effect of Organizational Commitment on Leadership Type and Job Performance" Journal of World Economic Research. Vol. 7, No. 1, 2018, pp. 14-20. doi: 10.11648/j.jwer.20180701.12

21. Luthans, F. (2011). Organizational Behavior. An Evidence-Based Approach, Twelfth Edition, New York: McGraw-Hill.

22. Mangkunegara, A.A. Anwar Prabu, (2009) Manajemen Sumber Daya Manusia Perusahaan. Bandung: Remaja Rosdakarya.

23. Meyer, J.P. and Allen, N.J. (1997) Commitmentin The Work Place: Theory, research, and applications: Thousand Oaks, California: SAGE Publication. Inc

24. Moeljono, Djokosantoso, (2003). Beyond leadership: 12 konsep kepemimpinan. Jakarta: PT. Elex Media Komputindo.

25. Mubarak Saleh, R.M., Nusari, M., Habtoor, N., and Osama Isaac. (2018) "The Effect of Leadership Style on Organizational Performance: Organizational Commitment as a Mediator Variable in the Manufacturing Sector of Yemen," International Journal of Management and Human Science (IJMHS), Volume 2, Issue 4, Pages 13-24, 2018 elSSN: 2590-3748 URL: http://www.ijmhs.org/index.aspx.

26. Nelson, D,L and Quick J,C. (2009). Organizational Behaviour Foundations Realities and Challenges. Thompson South Western. United States of America.

27. Rivai, Veithzal and Sagala, E.J. (2014). Manajemen Sumber Daya Manusia Untuk Perusahaan. Jakarta: PT Raja Grafindo.

28. Robbins, S.P. and Judge, T. A. (2015) Organizational Behavior 16th edition. England: Pearson.

29. Robbins, S. P. and Coulter, M. (2012). Management. New York: Pearson.

30. Robbins, S.P. (2003) Perilaku Organisasi. Buku 1. Edisi Indonesia Jakarta PT. Gramedia.

31. Robbins, S. P. (2010) Essentials of Organizational Behavior.Edisi ke-16, Salemba Empat. Jakarta.

32. Syaifuddin, D,T. (2005), Pengaruh Efisiensi Operasional Terhadap Market Share and Risiko serta Kinerja Bank Umum Swasta Nasional Devisa di Indonesia. Disertasi thesis Program Pasca Sarjana Universitas Airlangga. ADLN-Perpustakaan Airlangga.

33. Schein, E. H. (2004) Organizational Culture and Leadership. 5th edition. San Fransisco: Jossey-Bass Publishers.

34. Schemerhorn J, R; Richard N. Osborn, Mary Uhl-Bien, and James G. Hunt, (2012). Organizational Behavior. John Wiley and Sons Inc, Asia.

35. Sedarmayanti, (2016). Manajemen Sumber Daya Manusia Reformasi Birokrasi and Manajemen Pegawai Negeri Sipil. Bandung: Revika Aditama.

36. Sedarmayanti. (2007). Manajemen Sumber Daya Manusia. Cetakan Pertama. Penerbit Refika Aditama. Bandung. 
37. Sopiah, (2008) Perilaku Organisasional. Yogyakarta: CV. Andi Offset.

38. Srieati, L. (2016) "Influences of Leadership, Discipline, Work Environment, and Work Culture on Employee Performance viaMotivation and Organizational Commitment (Study in Dinas Kehutanan of Blora Regency)". Tesis dipublikasikan Program Magister Manajemen STIE-AUB Surakarta.

39. Suryaningsih, Ni Nyoman, A., Mareni, P. K., and Suardhika, I. N. (2018) Effect of Leadership and Organizational Culture to Employee Performance with Organizational Commitment as Mediation Variables on Jatayu Denpasar Earth Light Cooperation. Scientific Research Journal (SCIRJ), Volume VI, Issue II, February 2018 ISSN 2201 2796.

40. Sujarwo, E., Ratnasih, C., Sodikin, A. (2018) "The effect of organizational culture andenvironmentalwork on employee Performance through organization commitment pt.ciwangi berlian motor" International Journal of Business and Applied Social Science (IJBASS)Vol: 4, ISSUE: 5 May 2018 http://ijbassnet.com/ E-ISSN: 2469-6501.

41. Suwibawa, A., Putu Agung, A,A., Sapta, I Ketut S. (2018) Effect of Organizational Culture and Organizational Commitment to Employee Performance through Organizational Citizenship Behavior (OCB) as Intervening Variables (Study on Bappeda Litbang Provinsi Bali) International Journal of Contemporary Research and Review ISSN 0976 4852August, 2018Volume 09Issue 08. https://doi.org/10.15520/ijcrr/2018/9/08/582.

42. Terry, Goerge, R. (2001) Principle of Management, Sevent Edition. Homewood Illionois, Richsard D. Irwin Inc.

43. Thoha, Miftah (2004), Kepemimpinan dalam Manajemen Jakarta: PT. Raja Grafindo Persada.

44. Tosi, H.L., and Carrol, S. J. (1997). Organizational Theory and Management:A Macro Approach, John Willey and Sons Inc, New York

45. Wahjosumidjo. (2007). Kepemimpinan Kepala Sekolah. Jakarta: PT Raja Grafindo Persada

46. Yukl, G. (2013) Leadership in Organizations 8 Edition. New England: Pearson. 